\title{
THE INFLUENCE OF MINERALOGICAL COMPOSITION ON THE ADSORPTION CAPACITY OF HEAVY METALS SOLUTION BY JAVA NATURAL CLAY, INDONESIA
}

\author{
Wawan Budianta \\ Department of Geological Engineering, Faculty of Engineering, Universitas Gadjah Mada, Yogyakarta, \\ Indonesia, Tel: +62274513668, e-mail: wbudianta@ugm.ac.id
}

Received Date: May 7, 2020; Revised Date: August 21, 2020; Acceptance Date: October 21, 2020

\begin{abstract}
The adsorption capacity of four clay samples (Boyolali-BYL, Sleman-SLM, Gunungkidul-GK, and Pacitan-PCT) from Java, Indonesia, for copper $(\mathrm{Cu})$ lead $(\mathrm{Pb})$, zinc $(\mathrm{Zn})$ and cadmium $(\mathrm{Cd})$ solution was investigated by using batch equilibrium test. The adsorption data were presented using an isotherm curve, and adjusted to the Langmuir equation model, which produced the maximum adsorption capacity of the clay samples. The physical, chemical, and mineralogical analysis showed that the BYL and PCT samples have higher montmorillonite content, cation exchange capacity (CEC), and specific surface area (SSA) compared to SLM and GK clay samples. The batch equilibrium test revealed that the clay samples with higher montmorillonite content produced higher heavy metal adsorption capacity due to the higher cation exchange capacity (CEC), and specific surface area (SSA). The batch equilibrium test also show that the adsorption order for the metals cations followed the selectivity order $\mathrm{Cu}^{2+}>\mathrm{Pb}^{2+}>\mathrm{Zn}^{2+}>\mathrm{Cd}^{2+}$. The Langmuir model resulted in the adsorption processes, offering maximum adsorption capacities from 196.08 to $769.23 \mathrm{mg} / \mathrm{g}$ for $\mathrm{Cu}$, 217.39 to $416.67 \mathrm{mg} / \mathrm{g}$ for $\mathrm{Pb}, 106.38$ to $114.94 \mathrm{mg} / \mathrm{g}$ for $\mathrm{Zn}$ and 104.17 to $113.24 \mathrm{mg} / \mathrm{g}$ for Cd of four clay samples studied. The highest adsorption capacity was achieved for the BYL sample. The lowest was the GK sample, in which the order of the maximum adsorption capacity of clay samples was BYL > PCT > SLM > GK sample. This research indicated that the proportion of montmorillonite content in the clay samples affected the maximum adsorption capacity of the heavy metal in the solution.
\end{abstract}

Keywords: Adsorption, Batch test, Clay, Heavy metals, Java

\section{Introduction}

Nowadays, the presence of lead $(\mathrm{Pb})$, copper $(\mathrm{Cu})$, zinc $(\mathrm{Zn})$, and cadmium $(\mathrm{Cd})$, which are a heavy metals contaminant group that has toxic properties to humans and are usually found in waste [1,2]. Natural clay has physical and chemical properties to be able to adsorb heavy metals [3]. Several studies on natural clays' ability to adsorb heavy metals have been carried out using the batch equilibrium test, which is the simple but effective method $[4,5,6,7]$. The batch equilibrium test is a practical and quick test to predict the maximum amount of contaminants that can be adsorbed by a material and a representation of the experiment that can destroy all material structures; for example, the surface of the clay, which is an adsorbent medium. The batch equilibrium test is also carried out to measure the distribution coefficient $(\mathrm{K})$. A measurement of this $\mathrm{K}$ value is essential because it is an indication of contaminant retention by solids. Several studies have been conducted only for geological of natural clay deposit and mineralogy in Java, Indonesia $[8,9,10,11]$. However, the comprehensive research for the mineralogical composition of these natural clay influenced the heavy metals' adsorption need to be investigated. The study of heavy metal adsorption in natural clay is an 
important aspect, as stated by several previous studies $[12,13,3]$. This understanding of the adsorption will deliver knowledge for the use of natural clay for environmental remediation purposes.

This research aims to study characteristics and adsorption capacity on clay samples obtained from several locations in Java, Indonesia, and quantify the value of heavy metal adsorption. In this research, the batch equilibrium test was performed to obtain adsorption parameters, including maximum adsorption capacity $\left(\mathrm{Q}_{\max }\right)$ and adsorption constant, by calculating the Langmuir equation model determination. The Langmuir model is widely used because of its mathematical simplicity and also easily interpretable constant which related to the highest possible adsorption [14]

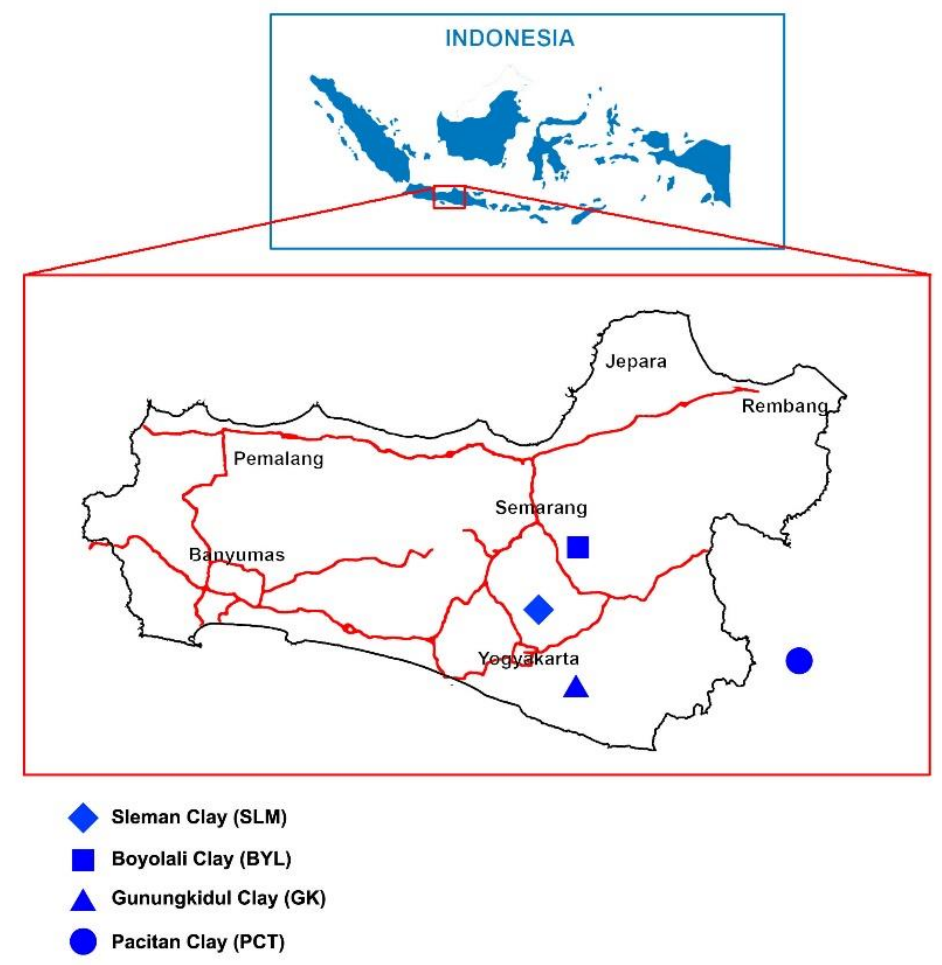

Figure 1. Sampling locations of clay in Java, Indonesia

\section{Materials and methods}

\section{Clay Samples}

The clay samples in this study were obtained from four locations in Java, Indonesia, with different geological backgrounds. They were the clays of Boyolali (BYL), Gunungkidul (GK), Sleman (SLM), and Pacitan (PCT). The sampling location can be seen in Figure 1, and the geological information on the clay samples can be seen in Table 1 based on other studies $[15,16,17,18]$.

Table 1. Geological Information of Clay Samples

\begin{tabular}{ccc}
\hline Clay Sample & Geological Formation & Clay Genesis \\
\hline Boyolali (BYL) & Kerek Formation & Volcanic glass alteration \\
Sleman (SLM) & Old Andesite Formation & Andesite intrusion alteration \\
Gunungkidul (GK) & Semilir Formation & Volcanic glass alteration \\
Pacitan (PCT) & Punung Formation & Volcanic glass alteration \\
\hline
\end{tabular}


Some of the main properties of clay samples were analyzed using the following procedure. The grain size was analyzed using the wet sieving and hydrometer method. The clay sample's pH was measured using a glass electrode, with a ratio of 1:5 for clay and water samples. The cation exchange capacity (CEC) of clay samples was analyzed by the $\mathrm{BaCl}_{2}$ method [19]. The specific surface area (SSA) of clay samples was measured by BrunauerEmmett-Teller (BET) method. The mineralogical content and types of clay minerals were analyzed using X-Ray Diffraction (XRD) technique. The XRD was operated using a Philips PW1710 diffractometer with Ni-filtered $\mathrm{CuK} \alpha$ radiation at randomly oriented samples. The quantitative assessment value of the mineral phases' presence was obtained from the XRD data, adopting the intensity of specific reflections and standard external variety of minerals [20].

\section{Batch Equilibrium Test}

The heavy metal adsorption experiment on clay samples was carried out using the batch equilibrium test. In this experiment, the adsorption performance of $\mathrm{Pb}, \mathrm{Cu}, \mathrm{Zn}$, and $\mathrm{Cd}$ was investigated in the clay samples used in this study that was done by preparing 10 grams of clay sample, which was placed in a 500-ml measuring cup. The desired eight heavy metal concentration solutions 5.0, 2.5, 1.25, 0.63, 0.32, 0.16, 0.08 and $0.04 \mathrm{mmol} / 1$ were prepared in this experiment at constant temperatures $\left(25^{\circ} \mathrm{C}\right)$. Then, $250 \mathrm{ml}$ of a solution containing $\mathrm{Cu}\left(\mathrm{NO}_{3}\right)_{2}, \mathrm{Cd}\left(\mathrm{NO}_{3}\right)_{4}, \mathrm{~Pb}\left(\mathrm{NO}_{3}\right)_{2}$, and $\mathrm{Zn}\left(\mathrm{NO}_{3}\right)_{2}$ has been added into the cup. The clay sample was dried, and then the batch test is carried out. The clay samples and heavy metal solution were stirred for 12 hours at room temperature and then were left without stirring for 24 hours. The agitation rates tested were $200 \mathrm{rpm}$, and the $\mathrm{pH}$ of the solution was kept on 6.5 . The mixture was filtered with a $0.45 \mu \mathrm{m}$ filter. The filtered solution was then analyzed for $\mathrm{Pb}, \mathrm{Cu}, \mathrm{Zn}$, and $\mathrm{Cd}$ concentration with the measurement of inductively coupled plasma atomic emission spectroscopy (ICP AES). All analyzes were carried out by making duplicates three times.

The maximum adsorption capacity $\left(\mathrm{Q}_{\max }\right)$ of the Langmuir isotherm equation for adsorption was calculated using the Equation [21]:

$$
\mathrm{Q}=\mathrm{Q}_{\max } \frac{K \cdot C}{1+K \cdot C}
$$

where,

$\mathrm{Q}=$ adsorbed amount $(\mathrm{mg} / \mathrm{g})$

$\mathrm{Q}_{\max }=$ maximum adsorption capacity $(\mathrm{mg} / \mathrm{g})$

$\mathrm{K}=$ adsorption constant $(\mathrm{l} / \mathrm{mg})$

$\mathrm{C}=$ initial metal concentration $(\mathrm{mg} / \mathrm{l})$

\section{Result and Discussion}

\section{Physical, Chemical, and Mineralogy of Clay Samples}

Several properties of clay samples are given in Table 2. The BYL and PCT samples had higher CEC and SSA values compared to the SLM and GK samples. This phenomenon occurred may be attributed to the montmorillonite-typed mineral had three layers, which were a repetition of one layer of alumina and two layers of silica. 
Table 2. Several Properties of Clay Samples

\begin{tabular}{ccccc}
\hline Properties & BYL & SLM & GK & PCT \\
\hline Sand (\%) & 12.3 & 22.3 & 19.9 & 17.9 \\
Silt-Clay (\%) & 87.7 & 77.7 & 80.1 & 82.1 \\
pH & 7.2 & 7.3 & 7.1 & 7.4 \\
Specific Surface Area (SSA) $\left(\mathrm{m}^{2} / \mathrm{g}\right)$ & 98 & 39.5 & 32 & 87 \\
Specific Gravity & 2.73 & 2.65 & 2.63 & 2.74 \\
Cation Exchange & 71 & 45 & 35 & 65 \\
Capacity (CEC) (meq/100 g) & & &
\end{tabular}

Generally, CEC and SSA values of four clay samples show that relatively intermediate compared with other natural clay that has been studied by another researcher $[22,23,24]$. Another study state that the CEC and SSA value of pure montmorillonite mineral up to $150 \mathrm{meq} / 100 \mathrm{~g}$ and $>100 \mathrm{~m}^{2} / \mathrm{g}$ [22] [25]. This difference may be due to differences in the percentage of clay minerals, and the existence of other mineral impurities like quartz. Also, this may cause for reducing the value of CEC and SSA, as found by other studies $[26,27,28]$

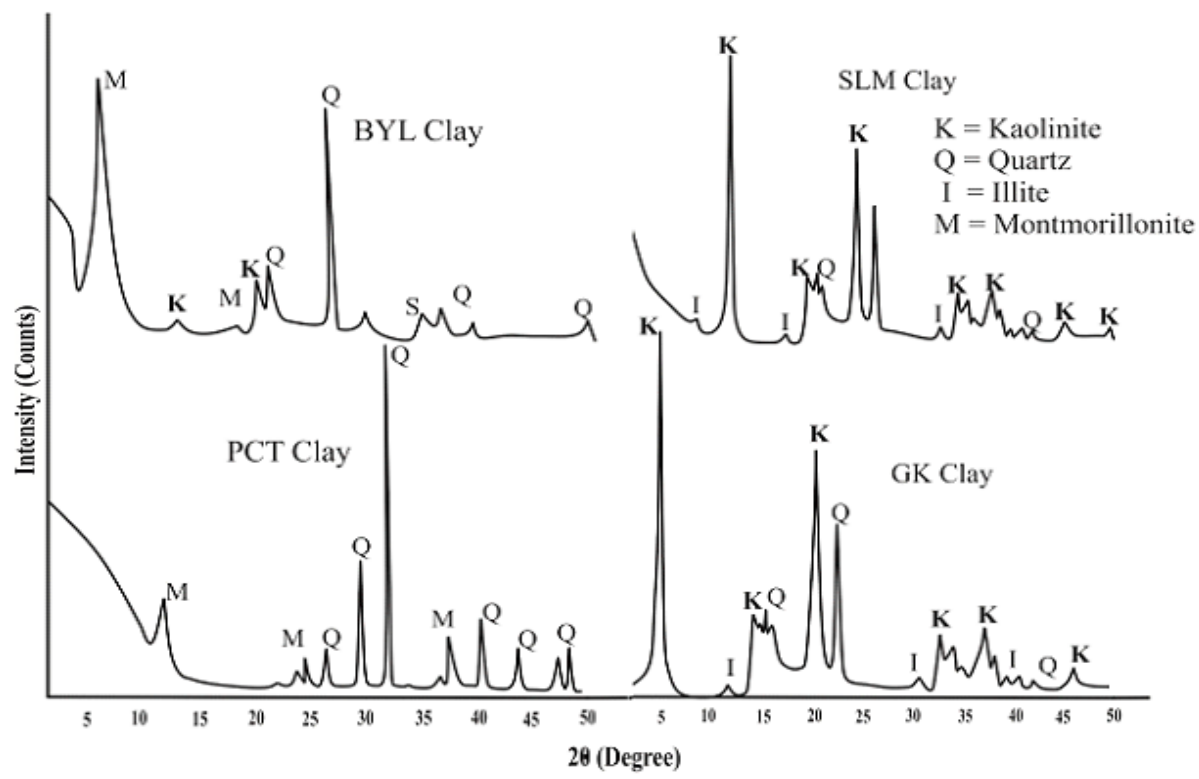

Figure 2. XRD diffractograms of samples showing the clay mineral identification

Figure 2 shows the result of the XRD analysis of the clay samples. The diffractogram of XRD indicates the presence of clay minerals such as montmorillonite, illite, kaolinite, but another impurity mineral such as quartz also present. These results have been confirmed by other researchers, which show that the existence of clay in the study area was heterogeneous of clay mineralogy contents $[8,9,10,11]$.

The semi-quantitative mineralogical composition is shown in Table 3. XRD analysis was found dominant for montmorillonite-type clay for BYL and PCT sample with percentages of montmorillonite $36.1 \%$ to $38.1 \%$, respectively. Other samples are found dominant for kaolinite-type clay for SLM and GK sample with portions of kaolinite $35.1 \%$ to $36.1 \%$, respectively. Other minerals such as quartz, plagioclase, feldspar, and other nonclay mineral were generally present in natural clay [29]. 
Table 3. Mineral Composition for the Clay Samples (\% wt)

\begin{tabular}{ccccc}
\hline Mineral variety & BYL & SLM & GK & PCT \\
\hline Montmorillonite & 36,2 & 14,1 & 17,1 & 38,1 \\
Illite & 6,5 & 6,7 & 5,7 & 7,4 \\
Kaolinite & 2,3 & 35,9 & 36,4 & 11,6 \\
Quartz & 17 & 16 & 21 & 18 \\
Plagioclase & 12 & 11 & 6 & 7,8 \\
K-Feldspar & 11 & 7,2 & 6,8 & 7,4 \\
Other non-clay minerals & 14,4 & 8,7 & 6,7 & 9,4 \\
Sum & 99,4 & 99,6 & 99,7 & 99,7 \\
\hline
\end{tabular}

\section{Result of Batch Equilibrium Test}

The result of batch equilibrium is shown in Figures 3 to 6 and Table 3. This test is conducted to obtain the $\mathrm{Q}_{\max }$ value of the clay by using eight solutions. Figures 3 to 6 show the linear relationship between the values $1 / \mathrm{Q}$ and $1 / \mathrm{C}$ used to get the Langmuir constant value $(\mathrm{K})$ and the $\mathrm{Q}_{\max }$ value. The adsorption data in this experiment was obtained from 1/Q plot value in the $1 / \mathrm{C}$ function as the Langmuir model representation.

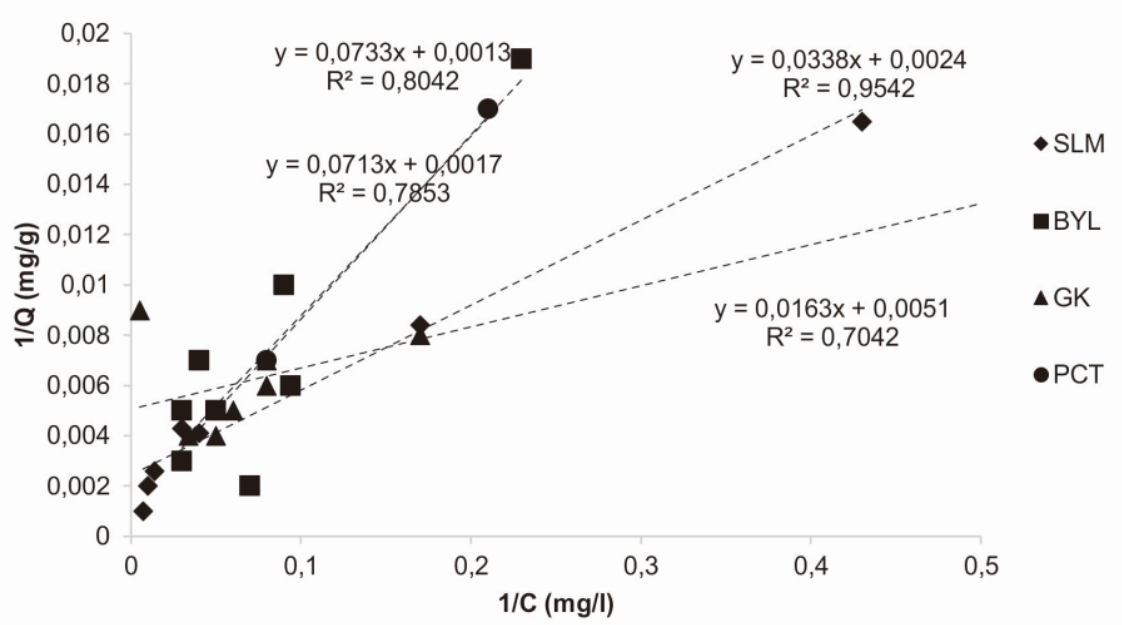

Figure 3. The linear relationship for $1 / \mathrm{Q}$ and $1 / \mathrm{C}$ of $\mathrm{Cu}$

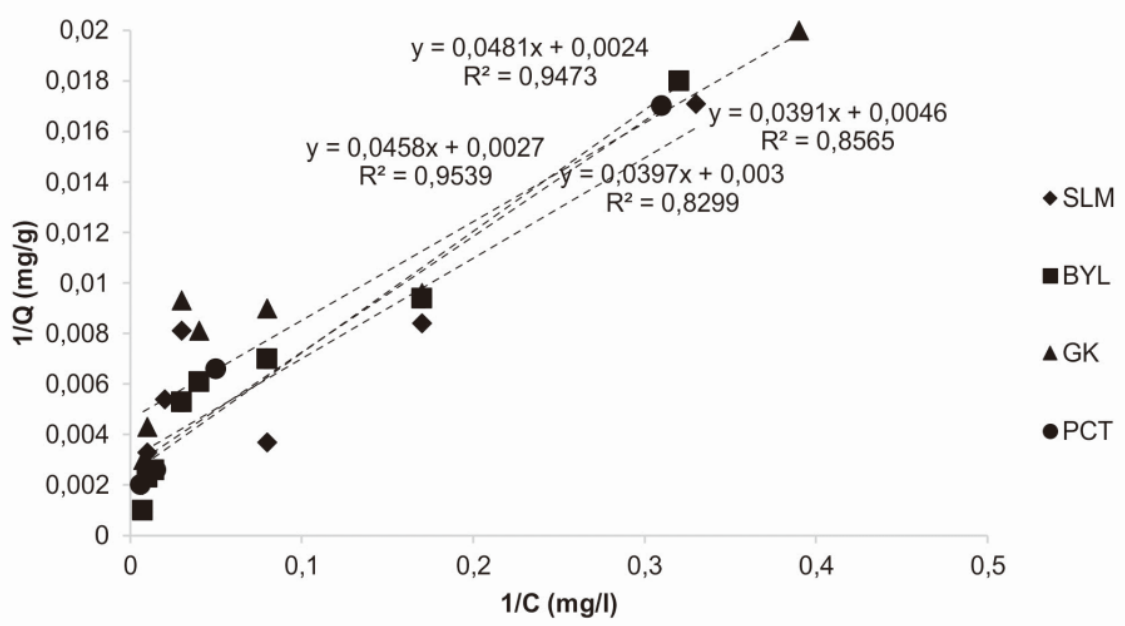

Figure 4. The linear relationship for $1 / \mathrm{Q}$ and $1 / \mathrm{C}$ of $\mathrm{Pb}$ 


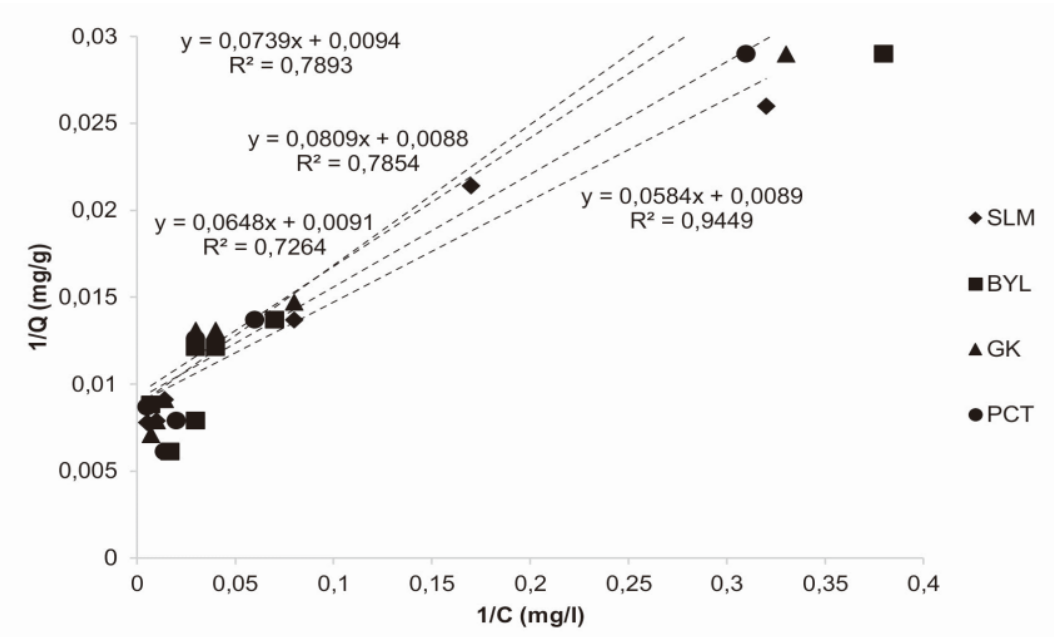

Figure 5. The linear relationship for $1 / \mathrm{Q}$ and $1 / \mathrm{C}$ of $\mathrm{Zn}$

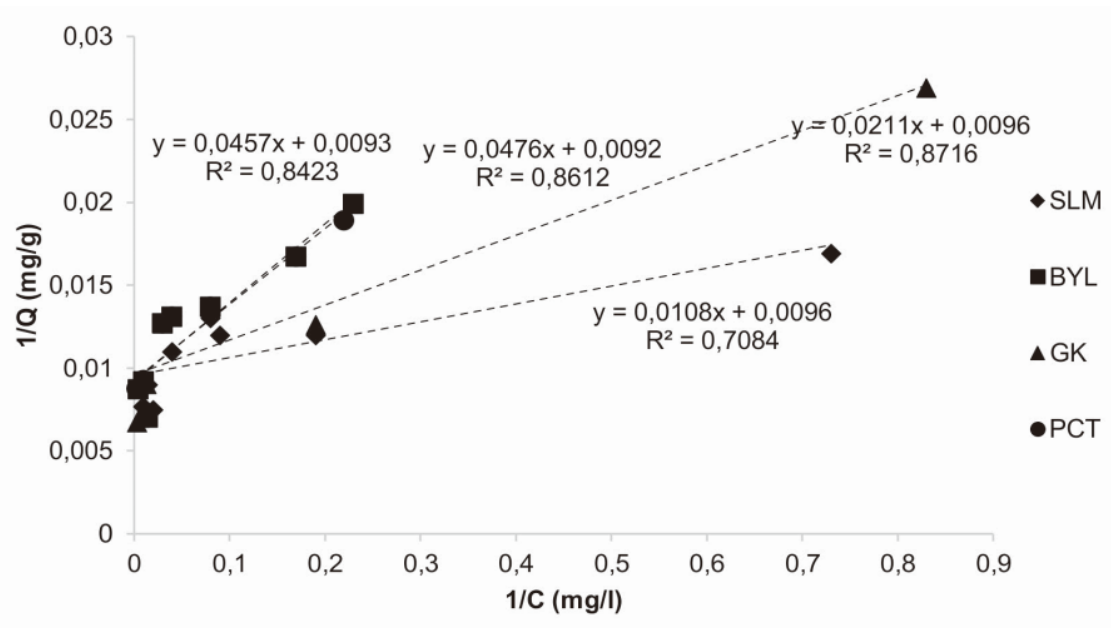

Figure 6. The linear relationship for $1 / \mathrm{Q}$ and $1 / \mathrm{C}$ of $\mathrm{Cd}$

Table 4 shows the amount of the $\mathrm{Q}_{\max }$ and $\mathrm{K}$ parameters, and the value of the linear regression, $\mathrm{R}^{2}$. Adsorption isotherm models were recommended to determine adsorption capacity, as stated by several studies $[30,31,32]$. In this experiment, the Langmuir equation model defines the tendency of adsorption data with values of $>0.70$ for $\mathrm{R}^{2}$, as shown in Table 4. This adsorption experiment indicates that the Langmuir isotherm model represents the adsorption progress with a high coefficient of determination. The coverage of metal cations on the clay samples' surface was reflected by the high $\mathrm{R}^{2}$ value obtained. In the Langmuir isotherm model, the equilibrium is limited to the molecular layer's determination and correlate to electrostatic chemistry in the outer sphere complex [33].

Table 4. K and Qmax Parameter from Experimental Data by the Langmuir Equations

\begin{tabular}{ccccccc}
\hline \multirow{2}{*}{$\begin{array}{l}\text { Samples/ } \\
\text { Parameters }\end{array}$} & \multicolumn{5}{c}{ Langmuir equations } \\
\cline { 2 - 7 } & $\mathrm{K}(\mathrm{l} / \mathrm{mg})$ & $\begin{array}{c}\mathrm{Cu} \\
(\mathrm{mg} / \mathrm{g})\end{array}$ & $\mathrm{R}^{2}$ & $\mathrm{~K}(\mathrm{l} / \mathrm{mg})$ & $\begin{array}{c}\mathrm{Q} \text { (max } \\
(\mathrm{mg} / \mathrm{g})\end{array}$ & $\mathrm{R}^{2}$ \\
\hline BYL & 0.017 & 769.23 & 0.804 & 0.049 & 416.67 & 0.947 \\
SLM & 0.710 & 416.67 & 0.954 & 0.075 & 333.33 & 0.829 \\
GK & 0.313 & 196.08 & 0.704 & 0.117 & 217.39 & 0.857 \\
PCT & 0.024 & 588.24 & 0.785 & 0.059 & 370.37 & 0.954 \\
\hline
\end{tabular}




\begin{tabular}{ccccccc}
\hline & \multicolumn{5}{c}{ Langmuir equations } \\
\cline { 2 - 7 } Samples/ & \multicolumn{5}{c}{$\mathrm{Cd}$} \\
\cline { 2 - 7 } Parameters & $\mathrm{K}(\mathrm{l} / \mathrm{mg})$ & $\begin{array}{c}\mathrm{Q} \text { max } \\
(\mathrm{mg} / \mathrm{g})\end{array}$ & $\mathrm{R}^{2}$ & $\mathrm{~K}(\mathrm{l} / \mathrm{mg})$ & $\begin{array}{c}\mathrm{Q}_{\max } \\
(\mathrm{mg} / \mathrm{g})\end{array}$ & $\mathrm{R}^{2}$ \\
\hline BYL & 0.107 & 114.94 & 0.723 & 0.455 & 113.24 & 0.800 \\
SLM & 0.127 & 112.35 & 0.945 & 0.888 & 106.13 & 0.708 \\
GK & 0.152 & 106.38 & 0.789 & 0.107 & 104.17 & 0.872 \\
PCT & 0.109 & 113.64 & 0.785 & 0.204 & 107.53 & 0.842 \\
\hline
\end{tabular}

The selectivity of four metals adsorption was exhibited by $\mathrm{Q}_{\max }$ values (Table 4), and the value was not similar for metals investigated. $\mathrm{Cu}$ and $\mathrm{Pb}$, the most greatly adsorbed metal in this experiment, were less influenced by competition than $\mathrm{Zn}$ and $\mathrm{Cd}$ for clay samples. This competition may be attributed to the fact that $\mathrm{Cu}$ and $\mathrm{Pb}$ were strongly adsorbed by the clay fraction and hence attempted effectively with the less adsorbed $\mathrm{Cd}$ and $\mathrm{Zn}$ and agree with another study [34]. $\mathrm{Cu}$ and $\mathrm{Pb}$ can enter clay lattices and form an insoluble group (e.g., $\mathrm{Cu}, \mathrm{Pb}(\mathrm{OH})_{2}$, as the alternative hydrolysis product of $\mathrm{Cu}, \mathrm{Pb}$ ). These are irreversible processes in a laboratory experiment range. They could cause an important constituent of $\mathrm{Pb}$ and $\mathrm{Cu}$ 's addition to be unavailable for cation exchange reactions. Another parameter influence the selectivity was related to the hydrated radius of the cation, as described by other researchers $[35,36]$. The hydration radius of the cations for $\mathrm{Pb}^{2+}(4.01 \AA)$, $\mathrm{Cu}^{2+}(4.19 \AA), \mathrm{Zn}^{2+}(4.30 \AA)$ and $\mathrm{Cd}^{2+}(4.26 \AA)$ respectively. Thus $\mathrm{Pb}$ and $\mathrm{Cu}$ seem to be less influenced by competition than other metals that are less adsorbed ( $\mathrm{Zn}$ and $\mathrm{Cd}$ ). The result revealed that $\mathrm{Pb}$ occupied a higher affinity for ion exchange on clay samples. This result of the selectivity is agreed with another researcher [37]. The adsorption of heavy metals ions on clay samples also depends on the ionic potential of the metals. The cations in the solution are connected with molecules of water in complex hydration. Generally, this hydration has a radius that was inversely corresponding to the cation radius. Hence, the smaller cations, the greater the hydration radius and cannot be easily eliminated from the clay surface. This finding also advises the low adsorption capacity of the $\mathrm{Zn}$ and $\mathrm{Cd}$ against the $\mathrm{Cu}$ and $\mathrm{Pb}$ component. In general, the adsorption order for the metals cations followed the selectivity order $\mathrm{Cu}^{2+}>\mathrm{Pb}^{2+}>\mathrm{Zn}^{2+}>\mathrm{Cd}^{2+}$.

Generally, the montmorillonite type-mineral has a higher adsorption capacity than the kaolinite type-mineral. The adsorption capacity values may reach as three times or higher [27]. Adsorption of heavy metals on clay samples appearance to follow Langmuir isotherm with a maximum adsorption capacity, i.e., $769.23 \mathrm{mg} / \mathrm{g}$ for $\mathrm{Cu}$ of BYL clay sample. This maximum adsorption capacity was decreased to 196.08 for GK clay samples (see Table 4). Metals adsorption on clay sample is sensitive to the montmorillonite content. In this study, the BYL and PCT clay samples have higher montmorillonite content than SLM and GK samples. Other studies revealed that Pb's adsorption by montmorillonite clay from $\mathrm{Pb}$ solution up to $20 \mathrm{mg} / \mathrm{g}$ [38]. It was determined that adsorption capacity is higher on dominant montmorillonite on BYL and PCT samples $(\mathrm{Cu}: 769.23 \mathrm{mg} / \mathrm{g}, \mathrm{Cd}: 588.24 \mathrm{mg} / \mathrm{g})$ than on kaolinite on SLM and GK samples (Cu: $416.67 \mathrm{mg} / \mathrm{g}, \mathrm{Cu}: 196.08 \mathrm{mg} / \mathrm{g}$ ). In another study, the better removal efficiency was obtained for heavy metals removal using montmorillonite instead of another type of clay [39].

The higher maximum adsorption values obtained in the BYL and PCT samples, and the lower values obtained in the SLM and GK samples, are shown in Figure 7. This adsorption capacity was consistent with the results of another researcher who stated that clay mineral type such as, for example, higher montmorillonite content, influenced the maximum adsorption capacity value [26]. 


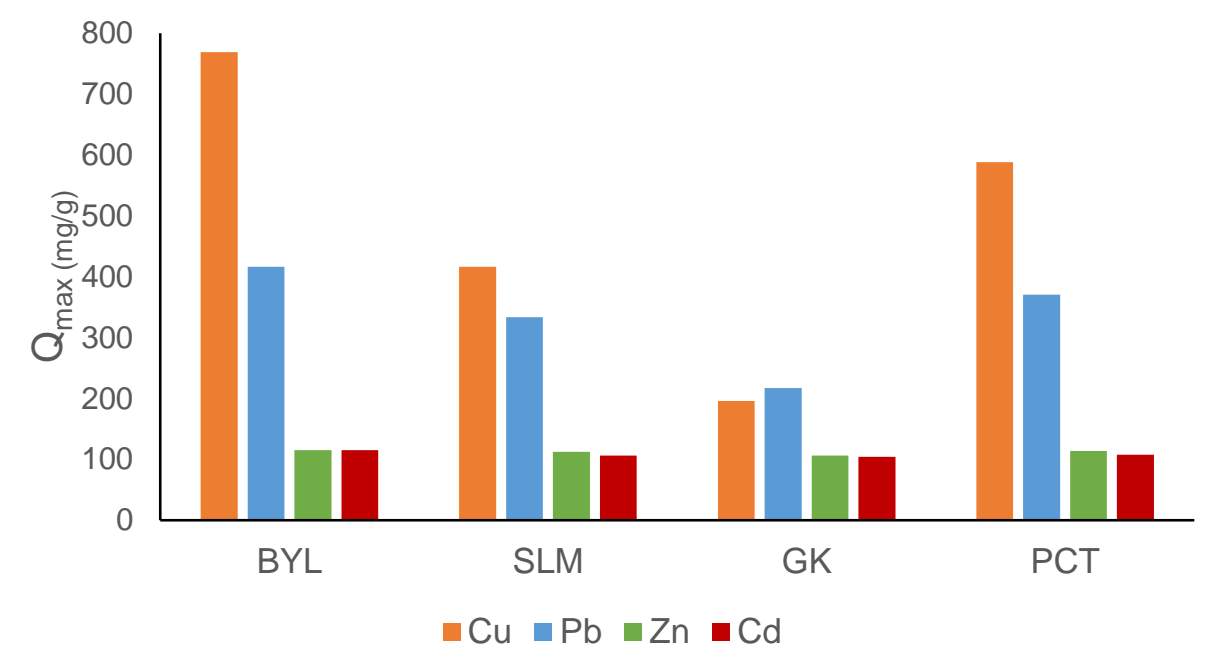

Figure 7. Comparison of adsorption capacity in four natural clay samples

Other research suggests that the high content of montmorillonite will provide high binding energy for metal absorption. The results obtained showed that clay samples had different behavior in adsorbing $\mathrm{Cu}, \mathrm{Pb}, \mathrm{Zn}$, and $\mathrm{Cd}$. This behavior might be related to the adsorption mechanism caused by the mineralogical content of the four types of clay samples studied, confirmed by other research [40]. These results indicated that the difference in the proportion of mineralogical contents in clay samples would affect the adsorption capacity of metal ions. This result shows that the order of maximum adsorption capacity of clay samples was $\mathrm{BYL}>\mathrm{PCT}>\mathrm{SLM}>\mathrm{GK}$ sample is obtained by analyzing the values of maximum sorption capacities calculated from the Langmuir equations,

The graphical correlation between maximum adsorption capacity $\left(\mathrm{Q}_{\max }\right)$, CEC, SSA, and \% montmorillonite values are shown in Figure 8-10. The graph in Figure 8 to 10 indicates a good correlation between maximum adsorption and CEC, SSA, and \% montmorillonite values with $\mathrm{R}^{2}$ values of more than 0.6. This result is agreed with other research results, which mentioned that clays with higher CEC, SSA value, and \% montmorillonite have higher adsorption values to adsorb metal cations [7, 41].

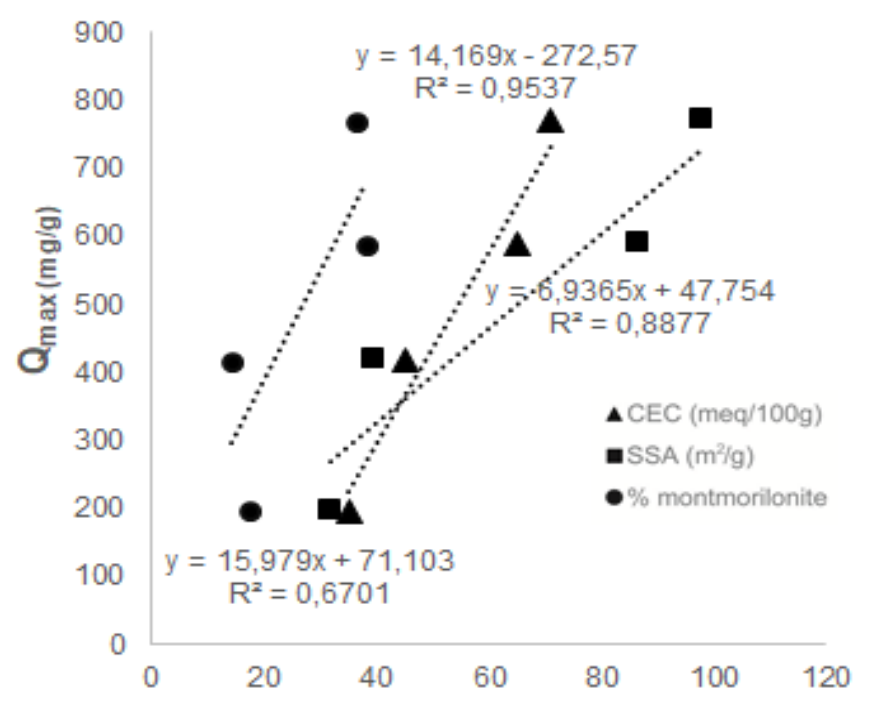

Figure 8. Graphical correlations $\left(\mathrm{R}^{2}>0.6\right)$ between maximum adsorption capacity, CEC and SSA value, and \% montmorillonite for $\mathrm{Cu}$ 


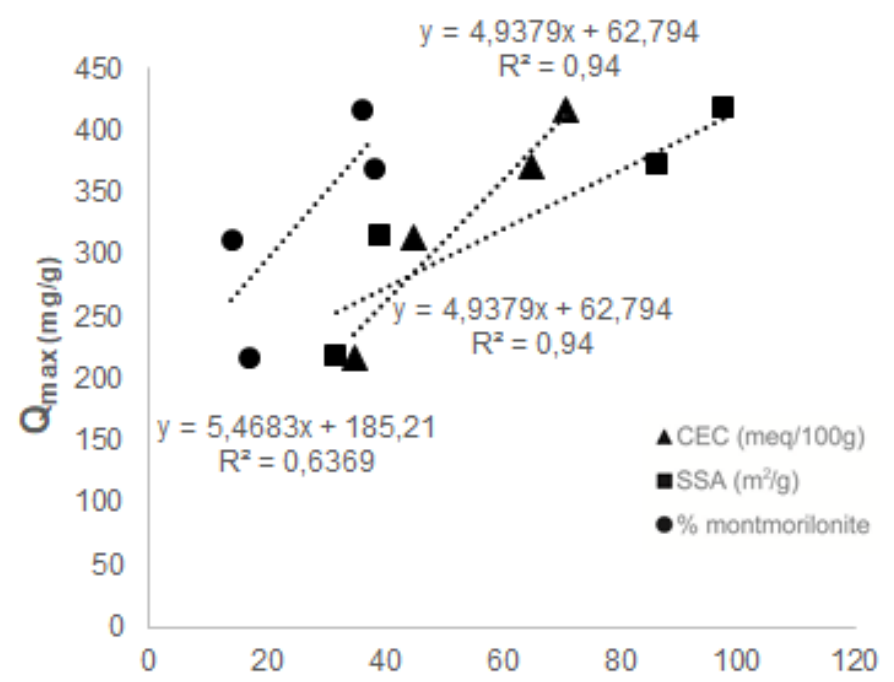

Figure 9. Graphical correlations $\left(\mathrm{R}^{2}>0.6\right)$ between maximum adsorption capacity, CEC and $\mathrm{SSA}$ value, and \% montmorillonite for $\mathrm{Pb}$

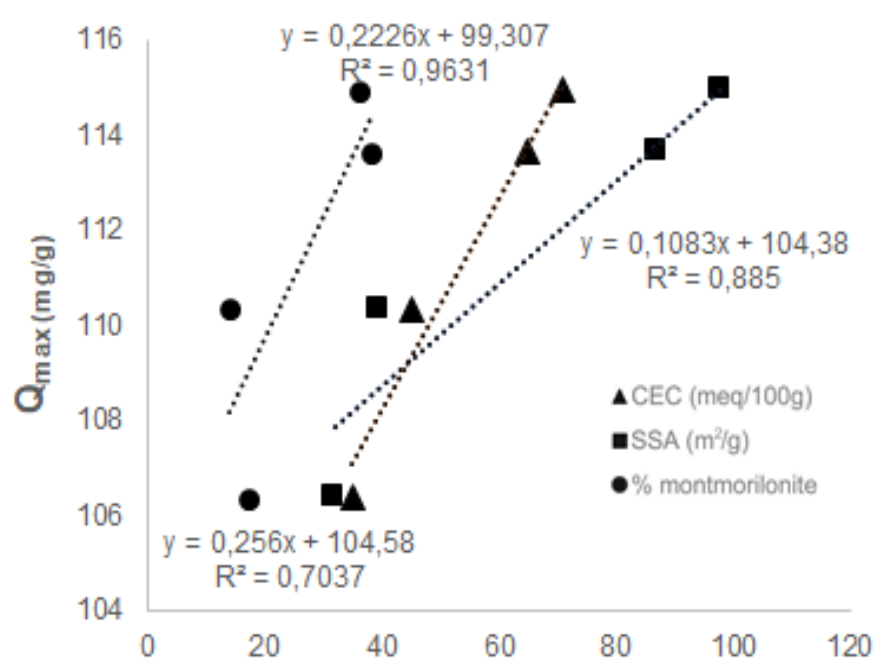

Figure 10. Graphical correlations $\left(\mathrm{R}^{2}>0.6\right)$ between maximum adsorption capacity, CEC and SSA value, and \% montmorillonite for $\mathrm{Zn}$

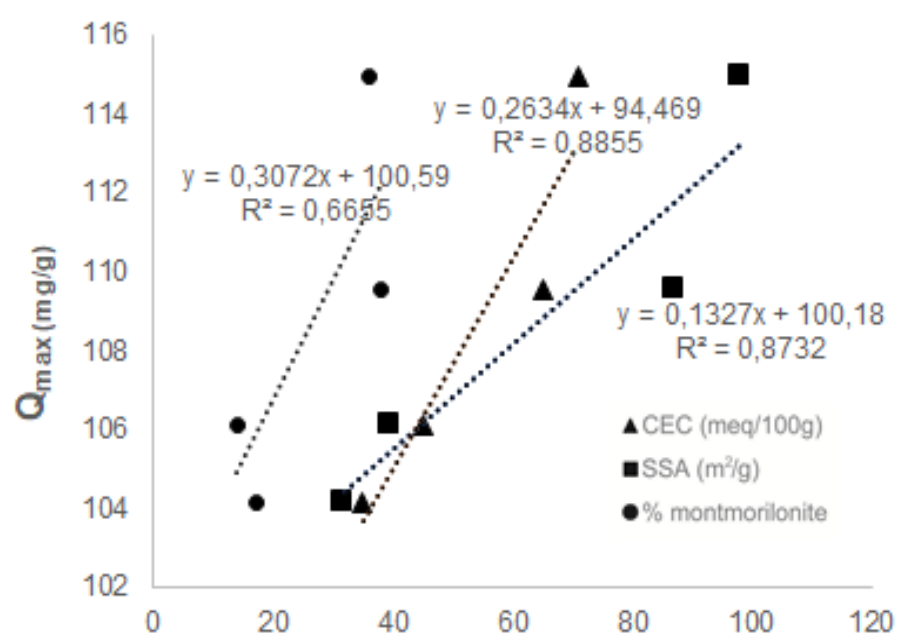

Figure 11. Correlations $\left(\mathrm{R}^{2}>0.6\right)$ between maximum adsorption capacity, CEC and SSA value, and \% montmorillonite for $\mathrm{Cd}$ 
Parametric Pearson correlation analyses were applied to the four parameters tested in pairs to assess the degree of association between the parameters examined. The $\mathrm{Q}_{\max }$ of $\mathrm{Cu}, \mathrm{Pb}, \mathrm{Zn}$, and $\mathrm{Cd}$ was strongly correlated with $\mathrm{CEC}$, SSA, and \% montmorillonite with Pearson's correlation coefficient of 0.01 and 0.05 level, as shown in Table 5. The results showed that CEC, SSA, and \% montmorillonite had a strong correlation with $\mathrm{Q}_{\max }$ of the four heavy metals. The trend shown by the $\mathrm{Q}_{\max }$ values in the Langmuir model also suggested that adsorption capacity increased with CEC, SSA, and $\%$ montmorillonite.

Table 5. Pearson's Correlation between Qmax and the CEC, SSA, and \% Montmorillonite $(n=4)$.

\begin{tabular}{cccc}
\hline Parameters & CEC & SSA & \% montmorilonite \\
\hline $\mathrm{Q}_{\max } \mathrm{Cu}$ & $.977^{* *}$ & $.942^{* *}$ & $.819^{* *}$ \\
$\mathrm{Q}_{\max } \mathrm{Pb}$ & $.935^{* *}$ & $.872^{* *}$ & $.728^{*}$ \\
$\mathrm{Q}_{\max } \mathrm{Zn}$ & $.898^{* *}$ & $.820^{* *}$ & $.675^{*}$ \\
$\mathrm{Q}_{\max } \mathrm{Cd}$ & $.880^{* *}$ & $.864^{* *}$ & $.713^{*}$ \\
\hline
\end{tabular}

Correlation coefficients marked by $*$ and ${ }^{* *}$ are significant at the 0.05 and 0.01 level, respectively (2-tailed).

The results indicated that the correlations between $\mathrm{Q}_{\max }$ and \% montmorillonite value more than 0.75 were the most significant, for $\mathrm{Q}_{\max }$ of $\mathrm{Cu}$. This highest correlation value may be attributed to the highest adsorption capacity (Figure 7). On the other hand, the correlations between $\mathrm{Q}_{\max }$ and \% montmorillonite value was less than 0.75 . This correlation value showed a lower degree of significance for $\mathrm{Q}_{\max } \mathrm{Pb}, \mathrm{Zn}$, and $\mathrm{Cd}$. This lower correlation value probably due to lower adsorption capacity (Figure 7). The statistical correlation of 0.01 and 0.05 level identified for \% montmorillonite strongly influenced on $\mathrm{Cu}, \mathrm{Pb}, \mathrm{Zn}$ and $\mathrm{Cd}$ adsorption.

\section{Conclusions}

This work investigated the adsorption characteristics of four clay samples obtained from Java, Indonesia, and measured the adsorption of heavy metals by batch equilibrium test to evaluate the adsorption parameters. The four clay samples were composed of dominant kaolinite contents for SLM and GK samples, while the BYL and PCT clay samples were mainly montmorillonite mineral. The adsorption capacity from batch equilibrium tests indicates that BYL and PCT have higher adsorption capacity on heavy metals than samples SLM and GK. The study also found a positive relationship between the adsorption capacity and the clay mineralogy content of the clay samples. The adsorption capacity of natural clay containing dominant montmorillonite-clay mineral is much higher than of kaolinite-clay mineral for all the four metal ions used in the experiment. The study also suggests that physicochemical characterization and batch equilibrium tests can be beneficial in assessing clay for an adsorbent material. Both clay samples containing dominant kaolinite-clay mineral and montmorillonite-clay mineral are capable of removing $\mathrm{Cu}, \mathrm{Pb}, \mathrm{Zn}$, and $\mathrm{Cd}$ from aqueous solution. This finding also shows that the proportion of different mineralogical content in clay samples is affected by heavy metal cations removal from wastewater. Future work for investigation of the study, such as the influence of $\mathrm{pH}$, should be considered in the batch test. Also, comparison by using another isotherm model such Freundlich isotherm need to be done to get a more comprehensive understanding of the adsorption study. Finally, tentative finding obtained in this study shows that clay samples in this study is suitable and has potential value for the adsorption of heavy metal contamination from wastewater, considering it is a low-cost, abundant, and locally available material. 


\section{Acknowledgment}

The author thanks the Japan International Corporation Agency (JICA) Project for AUN SEED-Net on Short Term Research Program (SRJP) program. The author also thanks to Tokyo Institute of Technology, Japan, for the support of laboratory experiments and analysis. The author thanks Professor Hirofumi Hinode and Dr. Winarto Kurniawan, for their valuable discussion and suggestion.

\section{References}

[1] L.D. Massaquoi, H. Ma, X.H. Liu, P. Y. Han, S.M. Zuo, Z.X. Hua, and D.W. Liu, "Heavy metal accumulation in soils, plants, and hair samples: An assessment of heavy metal exposure risks from the consumption of vegetables grown on soils previously irrigated with wastewater," Environmental Science and Pollution Research, Vol. 22, No. 23, pp. 18456-18468, 2015.

[2] F. Fu, and Q. Wang, "Removal of heavy metal ions from wastewaters: A review", Journal of Environmental Management, Vol. 92, No. 3, pp. 407-418, 2011

[3] B.O. Otunola, and O.O. Ololade, "A review on the application of clay minerals as heavy metal adsorbents for remediation purposes," Environmental Technology and Innovation, Vol. 18, p. 100692, 2020.

[4] S. Shu, W. Zhu, H. Xu, X. Fan, S. Wu, J. Shi, and J. Song, "A new method for determination of heavy metal adsorption parameters in compacted clay by batch tests," Ecotoxicology and Environmental Safety, Vol. 181, pp. 114-120, 2019.

[5] V. Antoniadis, J.D. McKinley, and W.Y.W. Zuhairi, "Single-element and competitive metal mobility measured with column infiltration and batch tests," Journal of Environmental Quality, Vol. 36, pp. 53-60, 2007.

[6] Y.J. Du, and S. Hayashi, "A study on sorption properties of $\mathrm{Cd}^{2+}$ on Ariake clay for evaluating its potential use as a landfill barrier material," Applied Clay Science, Vol. 32. No. 1-2, pp. 14-24., 2006.

[7] W.Y.W. Zuhairi, "Sorption capacity on lead, copper and zinc by clay soils from South Wales, United Kingdom," Journal of Environmental Geology, Vol. 45, pp. 236-242, 2003.

[8] W. Budianta, "Adsorption of heavy metal by natural clayey soil," Journal of Applied Geology, Vol. 3, No. 1, pp. 72-75, 2011.

[9] A. Yuliyanti, I.W. Warmada, and A.D. Titisari, "Characteristics and genesis of montmorilonitic claystone from Bandung area, Wonosegoro, Boyolali, Central Java, Indonesia" Journal of Applied Geology, Vol. 3. No. 1, pp. 64-71, 2011.

[10] W. Budianta, M.A. Popang, W. Prastistho, and J. Takemura, "Geo-mechanics and Hydraulic Conductivity Study of Claystone in Boyolali, Central Java, Indonesia" Journal of Applied Geology, Vol. 4, No. 1, pp. 20-31, 2019.

[11] W. Prastistho, W. Kurniawan, and H. Hinode, "Passive remediation of acid mine drainage using ball-milling modified Indonesian natural bentonite: Laboratory batch and column sorption of manganese," Green and Sustainable Chemistry, Vol. 8, No. 4, pp. 295-310, 2018.

[12] M.K. Uddin, "A review on the adsorption of heavy metals by clay minerals, with special focus on the past decade," Chemical Engineering Journal, Vol. 308, pp. 438-462, 2017.

[13] Y. Xu, X. Liang, Y. Xu, X. Qin, Q. Huang, L. Wang, and Y. Sun, "Remediation of heavy metal-polluted agricultural soils using clay minerals: A review," Pedosphere, Vol. 27, No. 2, pp. 193-204, 2017.

[14] G. Crini, E. Lichtfouse, L.D. Wilson, and N. Morin-Crini, "Adsorption-oriented processes using conventional and non-conventional adsorbents for wastewater 
treatment," In Green Adsorbents for Pollutant Removal, G. Crini, and E. Lichtfouse (eds.), [e-book], 2018 [Online]. Available: https://doi.org/10.1007/978-3-319-9211122

[15]. W. Prastistho, Geologi dan Aplikasi Lempung Wonosegoro, Boyolali Sebagai Liner Tempat Pembuangan Akhir (TPA) Sampah, Unpublished master thesis, Gadjah Mada University, Indonesia (in Indonesian language), 2015.

[16]. A. Hakim, Geologi dan Karakteristik Mineral Lempung di Perbukitan Godean, Kecamatan Godean dan Sekitarnya, Kabupaten Sleman, DIY dan Rekomendasi Pemanfaatannya, Unpublished undergraduate thesis, Gadjah Mada University, Indonesia (in Indonesian language), 2017.

[17]. B. Angraini, Geologi Daerah Karangsari dan Sekitarnya Serta Variasi Geokimia Endapan Kaolin Secara Vertikal Di Daerah Jetak, Kecamatan Semin, Kabupaten Gunung Kidul, Yogyakarta, Unpublished undergraduate thesis, Gadjah Mada University, Indonesia (in Indonesian language), 2009.

[18] H.D. Tatiwi, Geologi dan Genesa Bentonit di Desa Punung, Kecamatan Punung, Kabupaten Pacitan, Provinsi Jawa Timur, Unpublished undergraduate thesis, Gadjah Mada University, Indonesia (in Indonesian language), 2015.

[19] G.P. Gillman and E.A. Sumpter, "Modification to the compulsive exchange method for measuring exchange characteristics of soils," Soil Research, Vol. 24, No. 1, pp.61-66, 1986.

[20] L.D. Whittig, "X-ray diffraction techniques for mineral identification and mineralogical composition," In Methods of Soil Analysis: Part 1 Physical and Mineralogical Properties, Including Statistics of Measurement and Sampling, A. Klute, and A.L. Page (eds.), [e-book], 1965 [Online]. Available: https://acsess.onlinelibrary.wiley.com/doi/10.2134/agronmonogr9.1.c49.

[21] C.A.J. Appelo, D. Postma, Geochemistry, Groundwater and Pollution, $2^{\text {nd }}$ Edition, CRC Press, Balkema, Rotterdam, 2005.

[22]. G. Kahr, and F.T. Madsen, "Determination of the cation exchange capacity and the surface area of bentonite, illite and kaolinite by methylene blue adsorption," Applied Clay Science, Vol. 9, No. 5, pp. 327-336, 1995.

[23] K. Sakurai, A. Teshima, and K. Kyuma, "Changes in Zero Point of Charge (ZPC), Specific Surface Area (SSA), and Cation Exchange Capacity (CEC) of kaolinite and montmorillonite, and strongly weathered soils caused by Fe and Al coatings," Journal of Soil Science and Plant Nutrition, Vol. 36, No. 1, pp. 73-81. 1990.

[24] D.W. Rutherford, C.T. Chiou, and D.D. Eberl, "Effects of Exchanged Cation on the Microporosity of Montmorillonite," Clays and Clay Minerals, Vol. 45. No.4, pp. 534543, 1997.

[25] H.H. Murray, "Overview-Clay mineral applications," Applied Clay Science, Vol. 5, No. 5-6, pp. 379-395, 1991.

[26] K.G. Bhattacharyya, and S.S. Gupta, "Adsorption of a few heavy metals on natural and modified kaolinite and montmorillonite: A review," Advances in Colloid and Interface Science, Vol. 140, No. 2, pp.114-131, 2008.

[27] C.O. Ijagbemi, M. Baek, and D. Kim, "Montmorillonite surface properties and sorption characteristics for heavy metal removal from aqueous solutions," Journal of Hazardous Materials, Vol. 166, No. 1, pp. 538-546, 2009.

[28] N.D. Mu'azu, A. Bukhari, and K. Munef, "Effect of montmorillonite content in natural Saudi Arabian clay on its adsorptive performance for single aqueous uptake of $\mathrm{Cu}$ (II) and Ni(II)," Journal of King Saud University - Science, Vol. 32, No. 1, pp. 412-422, 2020 . 
[28] E. Erdem, N. Karapinar, and R. Donat, "The removal of heavy metal cations by natural zeolites," Journal of Colloid and Interface Science, Vol. 280, No. 2, pp. 309-314, 2004.

[29] J. Środoń, V.A. Drits, D.K. McCarty, J.C. Hsieh, and D.D. Eberl, "Quantitative X-ray diffraction analysis of clay-bearing rocks from random preparations," Clays and Clay Minerals, Vol. 49 No.6, pp. 514-528, 2001.

[30] O. Altın, H.O. Özbelge, and T. Doğu, "Use of general purpose adsorption isotherms for heavy metal-clay mineral interactions," Journal of Colloid and Interface Science, Vol. 198, No. 1, pp. 130-140, 1998.

[31] W. Budianta, N.D. Andriyani, A. Ardiana, and I.W. Warmada, "Adsorption of lead and cadmium from aqueous solution by Gunungkidul zeolitic tuff, Indonesia," Environmental Earth Sciences, Vol. 79, No. 172, pp. 1-11, 2020.

[33] M. Gutierrez and H.R. Fuentes, "A Langmuir isotherm-based prediction of competitive sorption of Sr, Cs, and Co in Ca-montmorillonite," Waste Management, Vol. 13, No. 4, pp. 327-332, 1993.

[34] J.C. Echeverria, M.T. Morera, C. Mazkiaran, and J.J. Garrido, "Competitive sorption of heavy metal by soils: Isotherms and fractional factorial experiments," Environmental Pollution, Vol. 101, No. 2, pp. 275-284, 1998.

[35] C.K. Danny, K. Chun, W. Cheung, K.H. Keith, F. John, and G. McKay, "Sorption equilibria of metal ions on bone char," Chemosphere, Vol. 54, No. 3, pp. 273-281, 2004.

[36] D.H. Lee and H. Moon, "Adsorption equilibrium of heavy metals on natural zeolites," Korean Journal Of Chemical Engineering, Vol. 18, No. 2, pp. 247-256, 2001.

[37] E.F. Covelo, F.A. Vega, and M.L. Andrade, "Competitive sorption and desorption of heavy metals by individual soil components," Journal of Hazardous Materials, Vol. 140, No. 1-2, pp. 308-315, 2007.

[38] R. Naseem, and S.S. Tahir, "Removal of $\mathrm{Pb}$ (II) from aqueous/acidic solutions by using bentonite as an adsorbent," Water Research, Vol. 35, No. 16, pp. 3982-3986, 2001.

[39] S.S. Gupta, and K.G. Bhattacharyya, "Adsorption of heavy metals on kaolinite and montmorillonite: A review," Physical Chemistry Chemical Physics, Vol. 14, No. 19, pp. 6698-6723, 2012.

[40] A.A. Zaki, M.I. Ahmad, and K.A. El-Rahman, "Sorption characteristics of a landfill clay soil as a retardation barrier of some heavy metals" Applied Clay Science, Vol. 135, pp. 150-167, 2017.

[41] A.L.Y. Abd-Elfattah, and K. Wada, "Adsorption of lead, copper, zinc, cobalt, and cadmium by soils that differ in cation-exchange materials," Journal of Soil Science, Vol. 32, No. 2, 271-283, 1981. 